\title{
Recreación narrativa de El celoso extremeño: Amad a la dama, de Gonzalo Hidalgo Bayal
}

\author{
Ana Calvo Revilla*
}

\section{INTRODUCCIÓN}

Gonzalo Hidalgo Bayal escribió Amad a la dama en 1996 durante un período de quince días, aunque no vio la luz hasta seis años más tarde (2002). Su publicación fue precedida por la aparición del poemario Certidumbre de invierno (1986), de las novelas Mísera, fue, señora, la osadía (1988) y El cerco oblicuo (1993), de la novela corta Campo de amapolas blancas (1997), de las fábulas que integran La princesa y la muerte (2001) y de los ensayos Caminos de Jotán (1994) y Equidistancias (1997). Con Amad a la dama obtuvo en 2003 el Premio Extremadura de Creación que otorga la Junta de Extremadura a la mejor obra literaria de un escritor extremeño publicada el año anterior.

Hidalgo Bayal se sitúa con Amad a la dama, obra palindrómica en su título, en el continuum de la tradición literaria, al adaptar el cuento tradicional del viejo celoso que custodia enclaustrando a una joven bella que, privada de su libertad, lo traiciona. Como ha subrayado Jorge García López (2001: 883), tres fuentes han disputado la génesis de este modelo literario: la narrativa bajomedieval; la literatura italiana, medieval o renacentista; y la literatura española del siglo XVI, la tradición folclórica. Lo encontramos en la Historia de Flores y Blancaflor (Menéndez Pelayo, 1905: CXLVIII-CXLIX), a través de la traducción castellana de 1600 (Bonilla, 1916); y también en las colecciones medievales de relatos moralizantes, como Disciplina clericales

\footnotetext{
* Universidad CEU San Pablo de Madrid
} 
(1948), de Pedro Alfonso (1062-1140), donde, con elementos procedentes de otras fuentes (sentencias de filósofos y sus comentarios, proverbios, fábulas y versos árabes, etc.), se ofrecen los consejos de un sabio a un joven antes de contraer matrimonio: ha de construir una casa con paredes altas y una sola ventana, en suma, una fortaleza que custodie a la persona amada, convirtiéndola en objeto y él en dueño de su propiedad; a pesar de lo cual, la mujer engaña con otro joven a su marido, tras emborracharlo y conseguir la llave que este escondía bajo su almohada (Cirot, 1929). Si para González Palencia, la base de la novela ejemplar cervantina estaría en un cuento popular marroquí de temática semejante que Cervantes habría conocido durante su estancia en Argel (1925: 417-423); para Avalle-Arce (1982) se encontraría en la recreación oral de las costumbres que se vivían en los monasterios griegos en el Monte Athos, donde se prohibía que vivieran mujeres y animales, unas costumbres que aparecen reflejadas en Embajada a Tamorlán (1582), de Ruy González de Clavijo o en Viaje a Turquía, de Andrés Laguna, que Cervantes habría cambiado de signo atribuyéndolas a Carrizales (2003: 34); mientras que Soriano (1972: 148) halla su fuente en la tradición europea, en la versión de Caperucita Roja, de Charles Perrault; García López considera que la simplicidad de la historia la emparenta con los patrones básicos del cuento folklórico (2001: 885) y temáticamente con la mitología (Dunn, 1973), de la que Cervantes hace un uso paródico (Gómez Íñiguez, 1991: 637).

Siguiendo la estela de Cervantes en su exploración de las posibilidades del arte narrativo, Amad a la dama recrea las aventuras y los cuidados enfermizos con que un marido celoso y suspicaz impide el acercamiento a su mujer de cualquier varón, subvirtiendo los hábitos de vida dignos de la naturaleza humana y las estructuras sociales, en el marco histórico de la guerra hispano-estadounidense de 1898 y de una Europa crispada, que conoció, entre otros acontecimientos mencionados en la novela, la gran guerra europea, la guerra con Marruecos, la guerra española, la segunda guerra mundial, etc. Nos encontramos ante la «parábola de un hombre sin estirpe» (2002: 4), de un hijo pródigo, que naufraga en el proceloso mar de la existencia humana y que, con sus celos extremos, con los desvaríos y desmanes del asedio hace de Leonor una cautiva. La primera secuencia, de las 46 que configuran la obra, es una anticipación de los preludios del desastre que se avecina. Cansado de bregar y preso de la soledad de sus pensamientos, de la desolación y del hastío que ha sembrado en su alma una actividad convulsa, presidida por la codicia y el trasiego de los negocios en la travesía de las grandes navegaciones, Felipe Carrizales se despide de la tierra del oro y regresa a España a descansar en la compañía de «una mulata llamada Guiomar y un negro polifacético que se llamaba Luis» (2002: 13). 


\section{INTERTEXTUALIDADES}

Gonzalo Hidalgo Bayal sigue, entre otras, la línea definida por Cervantes en una de sus Novelas ejemplares, El celoso extremeño, que guarda numerosas concomitancias con el entremés El viejo celoso, donde el protagonista, Cañizares, dotado de menor profundidad psicológica y complejidad, queda reducido a simple caricatura, propiciando un tono burlesco y satírico, una resolución obscena y un desenlace menos trágico. El escritor extremeño trabaja fundamentalmente (aunque no de manera exclusiva) sobre las dos versiones de la novela ejemplar: la publicada en 1613 y la anterior, del manuscrito de Francisco de Porras de la Cámara, fechado en 1606. Sobre la versión impresa de 1613 recrea el escritor extremeño algunos aspectos; por ejemplo, en Amad a la dama la dama se llama Leonor, variante de Leonora y no de Isabela, como figura en el manuscrito Porras, un cambio que introdujo Cervantes quizá para evitar el recuerdo del matrimonio contraído entre Felipe II e Isabel de Valois, como sostuvo Américo Castro (1957: 301-327). La dueña de la casa que compró Carrizales -llamada González, en la primera versión, y Marialonso en la de 1613, quien con perversión y sin escrúpulos pervierte a Leonora adiestrándola en los entresijos del adulterio-, se convierte en Amad a la dama en la cocinera María Alonso, que en la mansión de Santa Bárbara consume la mañana en preparar sabrosos guisos y que en su sordera es la única que permanece «ajena a la intensidad del drama» (2002: 109). La muchacha que actúa como centinela custodiando la puerta de la recámara del viejo en la primera versión, transformada en el personaje de Guiomar, una de las criadas negras en la versión de 1613, es, en la versión bayaliana, una mulata, homónima (2002: 13).

Son numerosas, asimismo, las resonancias cervantinas, varias tomadas de $E l$ Quijote, que hay en Amad a la dama. El protagonista de El celoso extremeño es Felipo de Carrizales, Filipo de Carrizales en Novela del zeloso estremeño, Cañizares en el entremés (nombre de la bruja en El coloquio de los perros) y Felipe Carrizales, en Amad a la dama. El nombre evoca la fragilidad del «carrizo», término con que se designa una planta silvestre de Venezuela, según la segunda acepción de la RAE: «gramíneas que tienen tallos largos, que se crían cerca del agua», y la del «cañizo», tejido constituido por «cañas y bramante o tomiza que sirve para camas en la cría de gusanos de seda, armazón en los toldos de los carros, sostén del yeso en los cielos rasos»). En el primer capítulo el narrador nos cuenta las intrigas surgidas en torno al nombre del protagonista:

\footnotetext{
Aunque hubo quien dudó de la autenticidad del nombre, Carrizales, y quien defendió con apasionamiento variantes verdaderas, Cañizares o Cañizales, o Cardizales, poco importa tan liviana divergencia a los efectos de la historia, sobre todo cuando, a fin de cuentas, en la voz de Murania se impuso Carrizales como apellido de mayor fortuna (2002: 9).
}

Los diversos nombres son juegos ficcionales con los que Hidalgo Bayal imita no El celoso extremeño sino El ingenioso hidalgo Don Quijote de La Mancha: 
Quieren decir que tenía el sobrenombre de Quijada, o Quesada, que en esto hay alguna diferencia en los autores que deste caso escriben, aunque por conjeturas verosímiles se deja entender que se llamaba Quejana (Parte I, cap I, 113).

Como ha precisado con sabiduría el escritor extremeño en una de las anotaciones de su blog, tanto la elección del nombre, en su condición etimológica de fragilidad, como la condición social de viejo hidalgo revelan uno de los rasgos cervantinos más sobresalientes: «una comprensión piadosa de la humana realidad» (2005). ¿No estamos nuevamente ante un rasgo muy bayaliano?

El celoso extremeño se abre con la partida de Extremadura de Felipo de Carrizales, hidalgo de origen nobiliario, y con la enumeración de sus peregrinaciones por España, Italia y Flandes hasta llegar a la ciudad de Sevilla, desde donde, una vez gastada su fortuna, partirá hacia Cádiz y desde allí hacia las Indias, «refugio y amparo de los desesperados de España, iglesia de los alzados, salvoconducto de los homicidas, pala y cubierta de los jugadores -a quien llaman ciertos los peritos en el arte-, añagaza general de mujeres libres, engaño común de muchos y remedio particular de pocos» (Cervantes 2003: 175); con cuarenta y ocho años llega al puerto de Cartagena, donde durante otros veinte amasará una gran fortuna. Amad a la dama, por el contrario, se abre con la expectación que provoca la llegada de Felipe Carrizales a Murania y la rumorología que su presencia provoca. Hubo quien dudaba de la autenticidad del nombre (Cañizares, Cañizales o Cardizales), quien murmuraba sobre su edad y sus orígenes en diversos pueblos de la confusa geografía española: Múrida o Andarón, Soz o Murganillos, etc.; nos encontramos con las alteraciones toponímicas del gusto de Bayal, por lo que entrañan de juego y divertimento con el lector: quizás Múrida por Mérida; Andarón por Pasarón; Murgañillos por Burguillos o Serranillos, municipios ubicados en Extremadura, hasta que el narrador nos dice que tomó cuerpo «por unanimidad la creencia de que era natural de la ciudad apócrifa y heterodoxa que ejerce el furioso contrapunto de Murania, la famosa Hépila, escenario acaso de su miseria infantil y de las primeras humillaciones $[\ldots] \gg(2002: 10)$.

¿Es casual esta mención de Hépila? No, cuando sabemos que quien escribe Amad a la dama es un avezado lector cervantino. Alude, no cabe duda, a la expresión «la famosa Hépila» que aparece en los ejemplares de la edición princeps de El Quijote, de Juan de la Cuesta, fechada en 1605, que se agotó en pocas semanas y que el mismo editor modificó en la segunda edición, al introducir algunas variantes, como la sustitución en el capítulo I de la I Parte de la expresión «por Epila famosa» por «por hacerla famosa» (118-119). La variante que presenta Amad a la dama, con acento esdrújulo y con $\mathrm{H}$ - inicial, es un guiño a Cervantes, no solo por la mención indirecta a El Quijote, sino por el empleo de la ironía en su burla a los libros de caballerías a través del juego gráfico que entabla. No existe Hépila con h-, pero sí Épila, sin h- inicial y con acento también esdrújulo; con esta grafía hace referencia a la población celtíbera, situada en la provincia de Zaragoza, sede de una imprenta famosa, 
de donde fue originario uno de los introductores en España del Renacimiento italiano: Jerónimo Jiménez de Urrea, traductor del Orlando furioso, de Ludovico Ariosto y de la Arcadia, de Jacopo Sannazaro, una obra que imitó en La famosa Épila, desaparecida hasta el momento, de cuya existencia tenemos constancia por la mención de Gutierre de Cetina en «De Gerónimo claro el apellido», donde afirma: «y la Epilia famosa / de Epila su patria gloriosa / las grandeza contiene» (1895, I: 127-128), con que quiso rendir homenaje a su tierra (Marín, 2002: 451-479). La famosa Épila que, calificada por algunos como novela pastoril, ha sido catalogada por autores como Juan Francisco Andrés de Uztarroz, sin embargo, como relato caballeresco en 1639, en Museo antiguo y moderno de los historiadores de Aragón y su corona: «La famosa Epilia libro cavalleresco no está impreso» (ms. 9457 de la BNM: 129), como sostiene Mañero Lozano (2000: 215-221). Jiménez de Urrea es, asimismo, autor de Clarisel de las flores, un libro de caballerías, que reproduce las principales situaciones del Amadís. Por consiguiente, esta mención bayaliana a la «ciudad apócrifa y heterodoxa que ejerce el furioso contrapunto de Murania, la famosa Hépila» es un guiño cervantino, con el que el autor de Amad a la dama se hace eco de los elementos paródicos de las novelas de caballería que plantea El Quijote.

En la quietud de la travesía oceánica, Carrizales, con la ayuda del negro Luis, descubre la lectura como remedio a sus males. A través de la lectura de la narración de las peripecias amazónicas, que contienen los relatos que escribió el ilustrado Alexander Von Humboldt a partir de los viajes de exploración del continente americano en Viaje a las regiones equinocciales del Nuevo Continente, Felipe Carrizales se adentra en los poderes mágicos de las palabras, en la fascinación de la letra impresa, dejando que su imaginación, como la de Don Quijote, se identifique con las hazañas narradas que han leído y que alimentan en su imaginación los sueños. Muy quijotescas son también las diversas referencias a la bibliofilia y sacralidad con que el negro Luis coge litúrgicamente el libro entre las manos, "como quien se adentra en bosque sagrado revestido de poderes sacerdotales» (2002: 15). Resonancias quijotescas tiene además el hecho de que María Alonso, la cocinera sorda que Carrizales llevó consigo entre su servidumbre -en El celoso extremeño es la dueña-, reciba en herencia de un segundo tío suyo, canónigo de la catedral, la biblioteca que la convirtió en la «heredera ilustrada» (2002: 37) -que no ilustre fregona-; Carrizales compró la biblioteca tras un «escrutinio» perplejo, hecho que presenta muchos ecos «del donoso y grande escrutinio que el cura y el barbero hicieron en la librería de nuestro ingenioso hidalgo». Entre los libros que había en la biblioteca (libros en latín de suma teología y filosofía, tratados de lógica y teodicea, libros de poesía y novela y crónicas de reyes de la biblioteca de autores españoles, etc.) figuran «las obras completas de Cervantes» (2002: 38). No falta el componente irónico y burlesco cuando el narrador señala que «el viejo Carrizales desconfiaba con toda intensidad de la literatura», especialmente de la poesía, pues era «un elogio enfermizo de la melancolía, y las novelas eran invenciones ociosas, pura sucesión inútil de 
peripecias falsas» (2002: 38), una desconfianza, como vemos, muy cervantina con la estigmatización de los libros de caballerías.

El matrimonio desigual recrea un tema típicamente cervantino, expresado en El celoso extremeño. En Amad a la dama, el eje de la trama gira en torno al enamoramiento de Felipe Carrizales de una muchacha de dieciocho años dotada de atributos de gran belleza, que vendía fruta en un puesto en el mercado de los martes de la Plaza Mayor de Murania y que a los ojos de nuestro hidalgo se transforma en una doncella, revestida de gran atractivo erótico y de los atributos mitológicos de Venus, diosa del amor y de la belleza, en definitiva, en una Venus del Bosque, como la denomina el narrador. El nombre de la dama es Leonor, joven originaria de Hoya del Juglar - escenario literario que quizás traduce los espacios natalicios del escritor extremeño, Higuera de Albalat-. Y Leonor es recreación del personaje femenino de El celoso extremeño, Leonora (denominada Lorenza en el entremés), una hermosa doncella de trece o catorce años, que descubre un día Felipo de Carrizales asomada al alféizar de la ventana de una casa, que muestra su condición sencilla, y que aparece también en El Quijote con motivo de la narración de la historia de los amores de Dorotea, joven burlada por don Fernando, cuando este le advierte del posible enojo de su padre por haberse casado con una villana, porque «nunca los tan desiguales casamientos se gozan ni duran mucho en aquel gusto con que se comienzan» (I, XXVIII, 397). Retoma Hidalgo Bayal la ubicación fotográfica de la hermosa doncella, si bien modifica el entorno; no se encuentra asomada a la ventana [que, según la interpretación de Maurice Molho, siguiendo los refranes de la época, reviste carácter de prostituta: «moza ventanera, o puta o pedera» (1990: 752)], sino en un puesto de la plaza mayor, pero expuesta a las miradas de todos, rasgo que cuadra con la simbología de la manzana, atributo de la Venus mitológica, impregnada de resonancias bíblicas, fruto prohibido que quebranta el vergel del paraíso y que acompaña iconográficamente la narración bayaliana.

La casa de doce mil ducados, que Felipo compra en el barrio de la ciudad, y que Cervantes presenta con una estructura arquitectónica conventual [«cerró todas las ventanas que miraban a la calle, y diólas vista al cielo» (2003: 180); «levantó las paredes de las azoteas de tal manera que el que entraba en la casa había de mirar al cielo por línea recta, sin que pudiesen ver otra cosa; hizo torno que de la casapuerta respondía al patio» (2003: 181)], se transforma en la obra bayaliana en la mansión de santa Bárbara. Hidalgo Bayal traslada a este escenario los atributos con que la crítica literaria ha revestido la fortaleza cervantina, cronotopo de un "convento sin espíritu», una «sepultura» (Casalduero, 1969: 177); una prisión (Forcione, 1982), un Hades (Duna, 1973: 104); en definitiva, una prolongación arquitectónica o «imagen gráfica del alma de Cañizares»(Percas de Ponseti, 1994: 140). Santa Bárbara pierde los atributos coloniales de la narración cervantina y adquiere los matices legendarios que la tierra de Murgaños (Casas del Juglar y Murania) reviste en la narrativa del escritor extremeño, también presentes en Amad a la dama. En Murania, capital de la Tierra de Murgaños, situada en los extremos del oeste nacional y 
a las orillas del río Murtes, y junto a la Sierra de Santa Bárbara, se encuentra la mansión homónima:

La casa de Santa Bárbara era entonces propiedad de los padres hervacianos, laboriosa donación de una herencia huérfana o beata, y sus ruinas eran la consecuencia de un estigma, el signo de una leyenda obstinada y trágica (2002: 25)

Sobre este escenario evoca el narrador en el capítulo 5 la leyenda placentina -ausente en la fuente ejemplar cervantina- relativa al edificio del siglo XVIII que mandó construir el cuarto hijo del marqués de Santa Bárbara, una de las víctimas del racionalismo ilustrado quien, con la soberbia de Faetón y con la presunción de Ícaro, a causa de un pacto secreto con el diablo y dada su condición de hereje descreído, fue asesinado un viernes santo, «crucificado en una cruz invertida» (2002: 25); fueron las voces populares las que lo relacionaron con la secta herética de los caballeros de la cruz invertida, construcción ficcional y divertimento que aparece prácticamente en todas las obras de Hidalgo Bayal.

Si etimológicamente «murgaño» es una tipología de arácnido, este territorio ficticio libera al escritor extremeño de las constricciones geográficas, históricas y sociales que le imponen las coordenadas espacio-temporales; como espacio imaginativo adquiere una dimensión simbólica y moral, alegoría universal de un territorio que fascina, cuyas ruinas - «techos hundidos, ventanas derrotadas, paredes torcidas, grietas intrépidas, bosques insomnes, brechas obtusas, suelos lastimeros» (2002: 28-29) - evocan la descomposición de un orden social en el que aún persisten los principios jerárquicos del antiguo régimen; las conjeturas, habladurías y sospechas de una ciudad de provincias, en la que persisten la endogamia y el aislamiento, que alimentan las luchas por el poder y el caciquismo. Conserva la mansión de Santa Bárbara el jardín de la casa cervantina; allí adquieren protagonismo las numerosas esculturas que decoran el escenario de la mansión (ménades, mercurios sedentes, neptunos, ninfas, sátiros o representaciones medievales del demonio o «bestión mascariento», quizá procedente del poema de Fernán González sobre el rey don Rodrigo), donde la ausencia de la estatua de mármol de la Venus del Bosque, pieza anónima que se encontraba junto a un recodo del Jayón -segundo revés de Carrizales desde su llegada a Murania tras su expulsión del casino- es la metáfora de su fracaso vital. La imposibilidad de adquirir esta pieza marmórea se convierte en la encarnación del deseo erótico de Carrizales de la nueva Venus del Bosque, la fruta de la primicia y la manzana bíblica que es la causa de la pérdida del paraíso. Ni la Venus del Bosque ni la manzana aparecen en las creaciones cervantinas, como tampoco la boda que se celebra en la iglesia parroquial de Casas del Juglar; el amor se expresa en imágenes de gran hermosura, que tiene resonancias místicas del Cantar de los cantares y el Cántico espiritual de San Juan de la Cruz:

Como perdurable era a los ojos del todopoderoso, según el abad, el matrimonio que ahora consagraban, una sola carne, un solo espíritu, una sola llama de amor viva en el vínculo de la amada y el amado (2002: 58). 
El escenario del paraíso bíblico es la mansión de Santa Bárbara, desligada de los atributos divinos, del diálogo amoroso, una topografía del solipsismo del alma que permanece en un «eterno soliloquio» (2002: 46):

\begin{abstract}
Habían convertido la vida de Santa Bárbara en una copia adecuada al paraíso: un dulce no hacer nada estático, un puro contemplar la belleza infinita de su propio dios inagotable, un modo de ser en plenitud, sin contornos exteriores ni necesidad de ingredientes ajenos, instalados en la totalidad de toda suficiencia (2002: 70).
\end{abstract}

Sin embargo, el narrador invierte la imagen mística del ciervo (representación de la agilidad con que el amado busca a la amada) en símbolo de la angustia: "Como un ciervo herido y solitario en una madriguera, como un lobo prendido por la dentadura asesina del cepo, así pasó Carrizales días de angustia en Santa Bárbara» (2002: 50). La celotipia y sus rituales, el aislamiento físico y social, se cobra sus víctimas: la vida sosegada se torna hastío; Santa Bárbara, cárcel; y el amor, cautiverio. Estas manifestaciones están presentes en El celoso extremeño, donde la casa es una alegoría de la muerte: «les pareció [a los padres de Leonora] que la llevaban a la sepultura» (2003: 181); «de esta manera pasaron un año de noviciado, y hicieron profesión en aquella vida, determinándose de llevarla hasta el fin de las suyas» (2003: 183). El secuestro adquiere tonos más crueles en la narración bayaliana, como muestran las secuencias 16 y 17 :

Por eso determinó acomodar las horas de su vida a la exigencia de aquel suplicio irreversible y multiplicar su asiduidad hasta los confines más recónditos de la patología amorosa. Llegó así a tales extremos que no había un minuto del día ni de la noche en que estuvieran separados. Urdió todos los pasos del futuro con la estrategia de una araña benéfica, como si la prisión fuera un bien para Leonor. No volvieron a bajar a Murania, salvo los paseos hasta el embarcadero por el camino de grava, ni se acercaron a Casas del Juglar, desoyendo tanto las súplicas de sus suegros como las insistentes invitaciones del alcalde, que sentía una afinidad fraternal con el viejo Carrizales y su pasado indómito, ni acudieron a fiesta alguna, ni al cine, ni a las obras teatrales que rara vez se dejaban caer por la ciudad en jiras de compañías mediocres por provincias (2002: 71).

Si algunos críticos han visto en la casa de El celoso extremeño elementos procedentes de la casa árabe, diseñada hacia el interior, esta está configurada también como prisión o fortaleza. En Amad a la dama, Santa Bárbara conserva los elementos mitológicos de la casa de la novela ejemplar, entrevista como el Hades clásico, que permanece bajo la vigilancia de Argos, en el que se esconden las manzanas de oro del jardín de las Hespérides. Carrizales es el Argos centinela que todo lo vigila: «De día pensaba, de noche no dormía; él era la ronda y centinela de su casa y el Argos de lo que bien quería» (2002: 184); y, a pesar de su resistencia a convertirse en el personaje mitológico de los cien ojos, que espía los movimientos de Leonor, muestra su naturaleza patológica: 
La tortura, sin embargo, alcanzaba también al propio Carrizales, pues, si el antiguo espíritu aventurero había avenido a la quietud por propia voluntad y había experimentado libremente la bonanza del sosiego, ahora la cualidad de la cautiva requería un solo tipo de guardián, un solo carcelero, que era él, de modo que el sosiego y la quietud se le antojaban igualmente forzosos, él mismo prisionero de su patología, esclavo de sus temores venecianos (2002: 73).

Carrizales es el rey del Hades que, tras concertar con el padre un matrimonio de común provecho, rapta a Leonor para hacerla reina del inframundo, de la sombría morada de los muertos; si nuestra Perséfone muraniense es la ninfa cautiva, Loaysa es Orfeo que seduce con el poder de la música y logra traspasar las fronteras y muros infranqueables. Loaysa, el músico, que en la versión de 1613 es llamado «virote, mozo soltero» que le había tomado ganas a conocer quién vivía dentro de la casa del recatado y celoso Carrizales (2003: 185) y que presume de conocer todas las tonadas del moro Abindarráez, logra convertirse, con el arrimo de la guitarra, en el Orfeo y maestro de Luis, el negro: «abrió la puerta, y recogió dentro a su Orfeo y maestro» (2003: 192). En Amad a la dama quien se presenta como un «verdadero pianista, un profesor de música» (2002: 84), es un aficionado que consagra sus ratos libres a la destreza del arte musical. Si la primera negativa de Carrizales a las peticiones que formulaba Leonor para eludir los muros inexpugnables de la prisión de Santa Bárbara fue la de desdeñar el plan pergeñado con Cristina para formar parte de la sociedad de amigas de la música -novedoso respecto a la narración cervantina-, la segunda negativa fue referida a la petición de acoger para darle clases a Leonor al joven profesor de música, pues este es considerado por Carrizales, a pesar de su ascendencia noble, como un «petrimetre del tres al cuarto, sin duda un alfeñique de poca monta, un granuja decadente, un seguro zascandil» (2002: 84), un «petrimetre imberbe y chisgarabís» (2002: 89). Con estos rasgos Hidalgo Bayal dibuja a un pícaro «artista advenedizo, sin consignas, en los límites del estar y el ser» (2002: 86), un ser sin norte y sin destino que, con su porte prerromántico y sus artimañas, presagia una ruina existencial, «disfrutando así de un paraíso de indigencia, manzanas de un edén cerrado» (2002: 92), derribando los muros de una prisión que no es solo arquitectónica sino personal. Este personaje se tiñe como en la novela cervantina de connotaciones sexuales.

Respecto a la solución final, las dos versiones de las Novelas ejemplares ofrecen una solución diversa; mientras en la versión Porras el adulterio se consumó tras el asalto de Loaisa (sic) a la casa de Carrizales [«Llegóse a esto el día, y cogió a los adúlteros abrazados» (2003: 258)]; no sucede así en la versión impresa de 1613, donde la escena ha sido mitigada: «Pero, con todo esto, el valor de Leonora fue tal, que en el tiempo que más le convenía, le mostró contra las fuerzas villanas de su astuto engañador, pues no fueron bastantes a vencerla, y él se cansó en balde, y ella quedó vencedora, y entrambos dormidos» (2003: 214). En este sentido, Amad a la dama opta por la primera resolución; en el capítulo 24, en el escenario paradisíaco de Santa 
Bárbara, se desatan fatalmente los elementos del drama y Carrizales descubre a los amantes, desnudos y dormidos, tras haber consumado el adulterio; anteriormente ya el narrador se ha referido al mismo: «Durante días buscaron con ansiedad decimonónica el modo de llevar a cabo sus propósitos, de burlar la vigilancia del viejo Carrizales para consumir la plenitud de sus ardores, pero no encontraban ninguna solución que excluyera la complicidad de la servidumbre» (2002: 92-93). Estamos ante una desviación culta, con que se alude, sin duda, al tópico de la novela del siglo XIX bajo la expresión «ansiedad decimonónica», que aparece explicitada en el capítulo 22:

Así fue, pues, con los papeles repartidos y ensayados, como finalmente Leonor y Loaysa, burlando la miopía usurera de Carrizales, derribaron los muros de la prisión y se deleitaron en el ejercicio impetuoso, vehemente e incendiario de su fogosa deflagración (2002: 96).

La imagen bayaliana dista de la resolución burlesca del entremés cervantino, donde Lorenza y el galán anónimo cometen el adulterio tras un tapiz (elementos descartados en Amad a la dama) y al ver a Cañizares entrar en la recámara, lo rocían con una bacía llena de agua jabonosa, que le ofusca la mente al pensar que le ha provocado una ceguera histérica; el escenario elegido para el drama por el escritor extremeño es el cuarto de Cristina.

En la versión Porras, Filipo de Carrizales, al coger a Isabela en «flagrante delicto», consciente de que ha fabricado el veneno que le ha quitado la vida, confiesa ante sus padres su culpa, y ante la afrenta e injuria recibidas decide no tomar venganza sino perdonarla con beneplácito mostrando así el amor que le profesa (2003: 260-261); no es otra la resolución en la versión impresa de 1613, donde también se explicita que la cólera se apoderó de Carrizales y se encaminó a tomar una daga «y volver a sacar las manchas de su honra con sangre de sus dos enemigos» (2003: 214). Sin embargo, en Amad a la dama Felipe Carrizales, según nos cuenta el narrador magistralmente en los capítulos 26 y 27, recreándose en la amargura de su alma y ahondando en el «hondo alcance del pecado original» (2002: 104), acaricia ante la cólera de Dios los deseos suicidas, vivencia con rigor cruel la fatalidad de los destinos humanos y la angustia del hombre y «prolonga su martirio en agonías lingüísticas», típicamente bayalianas, que justifican quizá la preferencia del escritor extremeño por Leonor en lugar de Isabel o Leonora; la respuesta la ofrece el narrador:

Pronunciaba o pensaba la palabra Leonor y se le antojaba la más amarga paradoja del destino y del lenguaje, que había incluido la palabra honor (Carrizales no sabía de ortografías ni pensaba las haches) en el nombre de la más desleal y pérfida de las mujeres). Así desgranaba una y otra vez los nombres, común y propio, desnudos, con la minúscula del pecado y sin conciencia heterográfica, en escalas crecientes y decrecientes: leonor, le onor, el onor, el onor, le onor, Leonor (2002: 106).

La estatua de mármol frío, en que se convierte Carrizales tras la amarga vista de Leonora en brazos de Loaysa (Cervantes, 2003: 214) se convierte, asimismo, 
en la narración bayaliana en la petrificación de su propia figura que, ahogada en la tristeza y en el llanto, experimenta «la metamorfosis del espanto» (2002: 101), adquiriendo tintes universales: «Carrizales se sentó inmóvil, contra la tarde, contra el paisaje, contra el tiempo» (2002: 101). El descenso del protagonista a los abismos infernales de los amores clandestinos que, magistralmente se tiñe de resonancias acústicas y desdibuja los contornos espacio-temporales, lo abocan al precipicio del remordimiento y al malestar de la culpa, «a las tribulaciones del pecado original» (2002: 102):

La palabra adulterio resonó en sus oídos repetida sílaba a sílaba con la furia de miles de pianos arrebatados en escalas crecientes y decrecientes, profanando su matrimonio, un dorremí infernal aullando desde los orígenes del tiempo y desde los infinitos recovecos de una pasión oculta (2002: 101).

A lo largo de los capítulos 27 y 28 de Amad a la dama, Hidalgo Bayal, con maestría narrativa y lirismo poético, revuelve en la conciencia de los personajes y perfila la teología del «mal adriático» y la amargura de la culpa. Lo hace magistralmente bajo el símbolo del Palacio Contarini del Bovolo, que los protagonistas visitaron en Venecia, escenario emblemático de la historia de amor que vivieron durante las dos o tres semanas más inocentes del matrimonio (2002: 64). No es un azar la elección bayaliana, totalmente novedosa respecto a la obra cervantina, de la compleja estructura laberíntica del palacio renacentista, que Pietro Contarini mandó construir a Giovanni Candi en 1499; con su torre cilíndrica horadada por arquerías abiertas, que dan unidad a cada una de las galerías de la fachada y que permiten contemplar la escalera de caracol («bovolo»), se habrá de superponer cronotópicamente la belleza del amor y su adulteración, la dicha y la desdicha. Las imágenes del palacio veneciano se superponen con fuerza cinematográfica a lo largo de numerosas secuencias narrativas. La subjetivización del espacio y los intricados mecanismos de la memoria impregnan la metamorfosis del edificio veneciano. La belleza de la construcción y su deteriorado estado de su conservación evocan el amor profanado y adulterado sobre el que Carrizales pretende renacer una nueva forma de amor, mixtura de lealtad y traición, sobre la que hace reposar «la candidez pecadora de Leonor» (2002: 110). En el capítulo 13 el palacio Contarini del Bovolo es el escenario de la sublimidad del amor y Venecia, el testigo de una felicidad sin mácula, sin embuste ni agravio, como testimonia la entrega de la gargantilla de intenso rojo veneciano con que Carrizales obsequia a Leonor, una exquisita pieza artesanal de cristal de Murano, obra de un artista ilegal y clandestino - a los artesanos del vidrio les estaba prohibido abandonar la isla de Murano-; sin embargo, persisten las impresiones pituitarias del «olor pútrido de los canales» (2002: 63), premonición de que «nunca se cumplen las grandes esperanzas, que siempre se esconde algo oscuro y turbio y desagradable en la cara oculta de la dicha» (2002: 64). Pronto, durante los paseos venecianos, las miradas lascivas y turbias, punzantes y dolorosas de los italianos serán el espejo que refleje la ciénaga patológica donde Carrizales guarda a Leonor 
como propiedad irrenunciable y objeto de deseo, causa de sufrimiento agudo y corrosivo, estéril, que lo convierte en una araña que teje la urdimbre de su propia muerte, y que hace de la mansión de Santa Bárbara una prisión, un espacio inhabitable y hostil, inhóspito al corazón humano.

Los personajes que protagonizan la narración bayaliana, solitarios e inadaptados al entorno en el que viven, solipsistas y misántropos, sin rumbo y sin destino, parecen abocados al fracaso; con acierto el escritor extremeño esculpe la amargura de la culpa a través de dos imágenes, que no se hallan en la narración cervantina, como tampoco la referencia a la triple negación de Carrizales a hablar con nadie: la quiebra del collar de Murano [icono del pacto sagrado que se había roto con la infidelidad cometida, magistralmente plasmado con su colocación en la mesilla de noche (2002: 100)], la rasgadura de los velos del templo y el vientre de la ballena donde expió su culpa el profeta bíblico:

Hasta que una tarde infortunada se sentó en el cenador para llorar su des-
ventura y encontró esparcidos por el suelo, rotos, deshechos, quebrados, los
restos menudos de la gargantilla veneciana, minúsculos añicos del tiempo
ido, destellos rojos de una pasión vencida y de un amor apócrifo. Enton-
ces se rasgaron los velos del llanto y la culpa se ahogó, cual soplo turco,
en la furia descompasada de un estrépito histriónico y en los borbotones
de la desesperación. Se encerró en su gabinete en actitud análoga a la de
Carrizales, cada uno en el vientre de su ballena cardinal, y aquellas com-
posturas que presagiaban calamidades, vistas y comentadas desde fuera por
la servidumbre, no dejaban de abundar en los ingredientes retóricos de una
comedia burlesca, porque la dignidad moral del hombre entra a menudo en
contradicción con los escasos méritos de la razón (2002: 109).

En el manuscrito Porras la estructura de la obra permanece totalmente cerrada con un desenlace trágico, protagonizado por la muerte (real o metafórica) de los personajes. Tras la muerte de Carrizales, la decisión de Isabela (Leonor) de profesar en el monasterio le lleva a Loaisa a alistarse en una jornada contra los infieles donde pierde la vida: «El, desesperado y corrido, dicen que se fué a una famosa jornada que entonces contra infieles España hacía, donde se tuvo por nueva cierta que lo mató un arcabuz que se le rebentó en las manos, que ya fue castigo de su suelta vida» (2003: 263). Prescinde Hidalgo Bayal de la interpretación que cierta crítica ha otorgado a la solución cervantina del manuscrito de Porras: que Loaisa costeó con su vida los excesos fálicos cometidos, pues el arcabuz era visto entonces como símbolo de poder sexual (Álvarez, 1990: 132). En la versión de 1613, la novela permanece abierta, pues Loaysa se va las Indias en busca de riquezas: «Él, despechado y casi corrido, se pasó a las Indias» (2003: 220). En esta segunda versión de El celoso extremeño, a través del senil Carrizales, y el donjuanesco Loaysa, Cervantes desdobla dos momentos de la vida de un único personaje. La estructura se torna circular pues convergen las vidas de Carrizales y Loaysa, quienes en momentos distintos de su vida hacen la «carrera de las Indias» para relegar a los espacios 
de la memoria los reveses e infortunios de la vida y acumular unas riquezas que les permitan vivir de las rentas. En 1613 Cervantes deja un desenlace abierto, que presenta «lugares o puntos de indeterminación», que han de ser rellenados por un lector activo a través de un proceso de «concretización», mediante el cual el lector incorpora su subjetividad y las vivencias del lector se funden con la objetividad inherente a la estructura del texto (Ingarden, 1931; Pozuelo, 1992: 111-112). El lector, con su imaginación, puede recrear el regreso de las Indias de este segundo Carrizales que es Loaysa. Pero no ha sido ese el camino elegido por el escritor extremeño en esta obra que recrea en la contemporaneidad la figura del indiano como personaje literario tópico en el Siglo de Oro, donde el narrador se limita a matizar que «Loaysa no había vuelto a Santa Bárbara, porque Leonor le previno» (2002: 108). ¿Qué fue de su vida? Aunque entonces nada más nos cuenta el narrador, posteriormente se nos dirá que «fue admitido de nuevo en la sociedad de amigos de la música» para poco después y por petición propia ser trasladado a una «vacante administrativa en la famosa Hépila» (2002: 121). Nuevamente la famosa Hépila.

Frente a la pretensión de historicidad con que se reviste el final de El zeloso estremeño [«el qual caso, aunque parece fingido y fabuloso, fue verdadero» (2003: 263)], la versión impresa de la novela ejemplar no termina con esta fórmula sino con una intencionalidad moralizante a través de un narrador en primer persona, que manifiesta su deseo de «llegar al fin de este suceso, ejemplo y espejo de lo que poco que hay que fiar de llaves, tornos y paredes cuando queda la voluntad libre, y de lo menos que hay que confiar de verdes y pocos años, si les andan al oído exhortaciones de estas dueñas de monjil negro y tendido y tocas blancas y luengas» (2003: 220-221). Amad a la dama conserva la tercera persona del manuscrito de Porras para prolongar el relato de la desolación que persiste en el alma, cuyo amor ha sido profanado, ya por el narcisismo codicioso de Carrizales, ya por la infidelidad y el adulterio de Leonor, como plasma la secuencia 28.

La estructura se torna circular en Amad a la dama; después de que el peso de la culpa atormente el alma de Leonor y cada uno sienta en sí el peso de la humillación, vuelve una paz de superficie a Santa Bárbara, que continúa siendo el escenario de la profunda lucha ambigua que sostienen entre sí el amor y el honor:

(...) concluía que la felicidad era básica y esencialmente imperfección, porque o era simple e inocente, y entonces carecía del suficiente grado de conciencia, un claro y peligroso predominio de la forma sobre la materia, la ingenuidad de Adán y Eva en un paraíso sin peligros, o era miscelánea e impura, un desmedido predominio de la materia sobre la forma, sometida a la tentación, curtida en el pecado, y entonces, mejorada su calidad, ascendida su conciencia, era más perfecta que felicidad, o sea, imperfecta (2002: 112).

Si en El celoso extremeño, tras la muerte de Carrizales, Leonora, «viuda, llorosa y rica» (2003: 220), se recluye en uno de los monasterios más recogidos de la ciudad, y Cervantes enfatiza la resolución moral y ejemplarizante 
al exponer el arrepentimiento de Leonora, subraya el misterio insondable y la impredicibilidad de la naturaleza humana ante los vaivenes de la vida y afirma la bondad natural del hombre (Forcione, 1982: 83), Amad a la dama, como veremos, a partir del capítulo 29 desarrolla una nueva trama, gana hondura intelectual y existencial, y redunda en reflexiones profundas acerca de la sombra de la culpa, las oscilaciones pendulares de los sentimientos amorosos, la imposibilidad de que el amor nazca de la unión de dos soledades y de modificar los trazos del destino: «Porque el amor es diverso, es ambiguo y es oscuro: nada hay en común entre el amor que arraiga en el escenario de la inocencia y el amor que se levanta, herido y arañado, de la espesura de la culpa» (2002: 113).

La introducción de nuevos escenarios y motivos, esencialmente narrativos, no modifican, sin embargo, la sustancia de la novela, que continúa girando en torno al eje central de los conflictos morales humanos, aunque innova respecto a la narración cervantina. En este sentido, nos parece que el capítulo 30 reviste un papel estructural de tránsito, pues sobre el motivo narrativo del viaje a Madrid se conjuga un nuevo tiempo y escenario, modificándose la percepción subjetiva del mismo. Si del primer viaje iniciático, que la pareja realizó a Madrid (invención del escritor extremeño), el narrador nos dice que fue «dulce y tibio», en el de ahora la ciudad se convierte en una imagen metonímica del amor amenazado: «era un viaje salado, de mediodía, en el que no sólo contaban los personajes de la historia como protagonistas exclusivos, sino que adquirían importancia, frente a ellos, los contornos de la ciudad y los menudos perfiles del placer exterior, en que el romanticismo daba paso al realismo neoclásico y al hedonismo objetivo» (2002: 116). Con genialidad narrativa, excelente dominio del lenguaje y voluntad de estilo, el narrador plasma el cambio con un oxímoron, tradicional en la poesía mística y amorosa: «Recorrieron de nuevo el primer escenario metropolitano, ahora de miel ácida y luna menguante» (2002: 115); o con la evocación metonímica del coche lujoso y de color negro «oscuro como una premonición» (2002: 119), que sustituye a la calesa y que con sus desplazamientos por las periferias de Murania y por Casas del Juglar es un presagio de la tormenta que se avecina en la que puede ser considerada como segunda parte de la obra y prolongación poética de la primera. La decisión de Leonor de permanecer obstinadamente enclaustrada, desoyendo la libertad de movimiento que le concedía Carrizales y obligándose a amar sustituyendo al negro Luis en la lectura del Madoz, introduce un elemento quijotesco, que es una de las constantes que permanecen a lo largo de la obra: el abandono de la lectura, en este caso de la biblioteca de autores españoles, como causa de los desvaríos, «de sus quimeras y persiles» (2002: 123) -neologismo que recategoriza el nombre propio en nombre común, otro guiño más a la obra cervantina Los trabajos de Persiles y Segismunda-.

En esta segunda parte, una de las innovaciones más destacadas es la prolongación de la trama mediante la introducción del personaje del pintor Hortigosa con $\mathrm{H}$, procedente del entremés cervantino, si bien cambia la condición sexual del mismo, pues Ortigosa deja de ser un personaje femenino (la vecina de Lorenza, 
quien la induce a cometer adulterio y que obtiene su fuente de la alcahueta Celestina) para dar vida a un joven pintor naturalista, «bien dispuesto, de aspecto musculoso y talante grave» (2002: 125), que es la complementariedad del viejo Carrizales; se traza así un paralelismo genial de la pareja formada por don Quijote y Sancho, si bien esta pareja Hortigosa/Carrizales es una clara parodia de aquella; como don Quijote, Hortigosa relata sus aventuras pintorescas, el recuento de sus gestas «en prestigiosas galerías y repertorios notables en museos de arte moderno» (2002: 126), mientras que, en paralelismo con Sancho, Carrizales «apenas sabía nada de tales historias, pues su única fuente de información era el diccionario geográfico, estadístico e histórico de España de Madoz, que solventaba con trazos gruesos los asuntos legendarios» (2002: 126).

A partir del capítulo 32 profundiza en el deterioro moral y humano de Leonor, que será objeto de la prolongación de la historia. Leonor, con su libertinaje «devino hetaira en bruto, ninfómana en precario, como aseguraba alguien que, llamándola siempre marquesa de Santa Bárbara, añadía, tras pausa malicia, que más bárbara que santa» (2002: 155).

Amad a la dama ofrece una estructura perfectamente equilibrada; su configuración a través de 46 secuencias o fragmentos de breve extensión prolonga la trama seguida por la novela cervantina e introduce un discurso secuencial próximo al cinematográfico y fílmico, al que nuestro escritor es tan aficionado. A partir del argumento, de los personajes y formas de ejecución cervantinas, Hidalgo Bayal aborda también en los capítulos que siguen una personalísima concepción del mundo y de los destinos humanos, penetra con radicalidad en el sentido de la vida humana, plantea interrogantes sobre la desigualdad en los matrimonios, reflexiona sobre los frutos amargos que se derivan de la negación de la libertad y del amor, los celos y el adulterio, y profundiza en el solipsismo y narcisismo de algunos comportamientos humanos. Concebida por el escritor extremeño como un divertimento, no estamos, sin embargo, ante una obra divertida, aunque su trama entretenga al lector. Nos encontramos ante una recreación en la que se imaginan variantes sobre las aflicciones que han atormentado y siguen atormentando al hombre. Como sucede en las obras cervantinas, vida y conocimiento aparecen indisolublemente entrelazados; las tribulaciones y tormentos, las pesadumbres y congojas que acompañan la existencia de los personajes bayalianos deambulan inextricablemente entretejidos con sus reflexiones y pensamientos hasta adquirir una validez universal. $\mathrm{Si}$, como sostuviera Avalle-Arce en Nuevos deslindes cervantinos, la vida de don Quijote y de los personajes cervantinos lleva en sí las formas embrionarias de todas las vidas humanas, no se puede decir menos de la validez universal que encierran los pensamientos ensimismados de Felipe Carrizales y las formulaciones del deseo por parte de Leonor. A pesar de los cálculos abstractos con que Carrizales había proyectado la construcción del escenario de los celos, tras el desvelamiento del adulterio de Loaysa, se impone la verdad. En El celoso extremeño se nos dice:

Mas como no se puede prevenir con diligencia humana el castigo que la voluntad divina quiera dar a los que en ella no ponen del todo sus deseos y 
esperanzas, no es mucho que quede defraudado en las mías y que yo mismo haya sido el fabricado del veneno que me va quitando la vida (2003: 218).

\section{Y en Amad a la dama:}

No se trataba de un propósito ni de una forma de venganza, sino de la necesidad crucial de padecer a solas su dolor, de arrepentirse de su demencia, de apurar la amargura de su insensatez, de cuajar en piedra el esquivo volumen glacial de su alma, a la espera de la derrota o de la metamorfosis (2002: 110).

Desde la perfección palindrómica del título que enmarca Amad a la dama, la lectura de la obra revuelve la conciencia del lector, que se ve encerrado en un juego de espejos, donde se proyectan los paralelismos que mantiene el texto con las fuentes literarias; en clara correspondencia, los espacios que configuran el escenario narrativo se transforman en un laberinto, constituido por el ámbito de la casa que construye Carrizales, habitada por unos seres que deambulan sin horizonte vital y pervierten el orden familiar, social y moral establecido y transforman el edén del paraíso en un infierno, donde la complejidad de cada personaje se transforma para el otro en una espiral, en un enigma, cuyas acciones son indescifrables, contribuyendo así al ambiente laberíntico y espiral de la obra. Como sostuvo Francisco Ayala en su estudio de las novelas ejemplares cervantinas, se le puede aplicar a esta novela bayaliana la defensa de un orden ético natural, pues sus criaturas buscan «sus reglas de conducta no en las normas establecidas por un sistema ético o moral impuesto desde el exterior, sino en su propia naturaleza íntima» (1954; 1972: 689). Se acentúan en Amad a la dama las resonancias bíblicas, entre ellas, algunas alusiones paganizadas a los ritos de la liturgia, vinculados al acto de la lectura; el edén del paraíso; las manzanas, «un discreto envoltorio de verdes doncellas tentadoras» (2002: 42); los argumentos piadosos con que Carrizales intenta paliar la «infamia y perversión, blasfemia y sacrilegio» que perpetúa con su terca y turbia pretensión de asediar a la joven y trasgredir las siete etapas de la vida humana: nacimiento, niñez, adolescencia, juventud, virilidad, vejez, decrepitud (número impregnado de resonancias bíblicas), haciéndola pasar de la segunda a la cuarta; el matrimonio; la mediación maternal de la Virgen y la ermita de San Hervacio (mutación de San Gervasio); los designios de la providencia; las tres negaciones de Carrizales que evocan las de Pedro; el pecado original; el vientre de la ballena profética; el remordimiento y la culpa; el perdón de los pecados; la unción de los enfermos, etc.:

Leonor, por su parte, tampoco era la muchacha que vendía fruta en el martes ni la aspirante a dama musical, sino la personificación de una dolorosa antigua, surcada por todas las huellas del arrepentimiento, marcada por la imposibilidad de rebatir o anular el pecado original. Tantas y tales lágrimas derramó Leonor, tan humillada estuvo y tan patética, tan transido era el brillo de sus ojos, que Carrizales vio en la mirada del dolor y del remordimiento la misma hondura que en la del amor junto al Palacio Contarini del 


\begin{abstract}
Bovolo y vio que las conjunciones entre amor y dolor eran permanentes y necesarias y que no existían sentimientos puros, sino mixtos, trenzados y su desgraciada condición (el corazón es un músculo frágil, pensó, ciénaga y pesadumbre), y, aunque no perdonó la traición, o, dicho de otra forma, aunque supo que, por mucho que perdonara la traición, el amor profanado por el pecado original era irrecuperable, presintió otra distinta forma de amar, seguramente más humana, probablemente imperfecta, una forma mixta de lealtad y traición, el gozo de la redención, y acogió en sus brazos de nuevo la candidez pecadora de Leonor, casi con la esperanza de que, a la postre, hubiera una leve compensación en el engaño y un germen de armonía en el adulterio, en tanto se afanaba la mulata Guiomar inútilmente en el jardín articulando palabras exóticas sobre un vaso en el que Carrizales había bebido ron (2002: 110).
\end{abstract}

Cobra este aspecto especial relieve en la secuencia 35, donde recrea la tristeza de Leonor, vista como una dolorosa que persevera en su martirio, como una Penélope homérica que en su labor de «tejer y destejer la tela» no admite fármacos que alivien la melancolía que atenaza su alma. Amad a la dama alcanza un diseño arquitectónico en las sucesivas anunciaciones del ángel profano del señor, tres, que, aparte de las concomitancias que presentan con las resonancias bíblicas mesiánicas (la anunciación a la Virgen, a los magos de Oriente y a los pastores), evocan el ángel de la historia de Walter Benjamin, su concepción de que la teología puede enseñarnos a tomar distancia de la inmediatez de la historia: la primera ocurrencia tuvo lugar en una de las correrías de Carrizales en su nuevo haiga por la Hoya del Juglar; bajo el aura de la estatua de la Venus del Bosque que Carrizales no había podido adquirir, tuvo «un golpe de de inspiración moral que desechó sin embargo con prontitud por utópico y arrogante»; no cabe duda de que el narrador juega con el lector (2002: 119). La segunda anunciación tuvo lugar en el Caserón del Sueco que habita Hortigosa, la luz de que «ni el azar ni la providencia traman casualidades huecas» (2002: 127). Y la tercera revelación artística, fruto de la aparición en la mente de Carrizales de los tres iconos que han alimentado y quebrantado su relación con Leonor: la gargantilla veneciana pulverizada en el cenador, el viaje a Madrid y el rechazo de la dama, que le llevan a imaginar un nuevo fetiche que plasme la inmortalidad de Leonor: una escultura en mármol de la joven juglareña, exactamente igual que la Venus agreste de la Hoya del Juglar, que conmemore «los días del presente y los trabajos del amor» (2002: 130) -un guiño quizá al poema de Hesíodo, Los trabajos y los días - y que encarga esculpir al pintor para instalarla en el centro del jardín de Santa Bárbara, un motivo que genera la historia que narra entre los capítulos 36 y 42 . El motivo escultórico, Leonor en persona, reúne en sí todas las imágenes clásicas de la belleza femenina; es una Venus calipigia de hermosas nalgas; una canéfora que porta sobre su canasto las manzanas de la tentación; es una cariátide o una Niké, que ejerce una atracción hipnótica sobre el pintor hasta que entre ambos creen «una sintonía de enamorados sinónimos» (2002: 139). Con esta imagen se deja abierta la puerta de la interpretación al lector que ha de dilu- 
cidar si se trata de la sinonimia de la lascivia e impudicia que los capítulos siguientes recrean mediante el bosquejo de la perversión del deseo erótico de los dos amantes, cuya consumación esta vez no alberga el arrepentimiento de la Leonor de carne y hueso, «mujer de ida y retorno» (2002: 149), que había hecho de Carrizales -según describe con virtuosismo lingüístico el narrador«un escultor a su vez de una estatua de ortigas» (2002: 149), que conocedor de «los entresijos turbios del triángulo» y de los hiperbólicos abrazos, decide legar al mundo «un testimonio cierto y verosímil de la belleza que atesoraba la mujer que le complació tan amorosamente en los últimos años» (2002: 152). ¿Cabe más burla y más locura en el autoengaño? ¿No ha elaborado Carrizales un mito? ¿No estamos ante un proceso de sublimación semejante al que don Quijote traza con Dulcinea? ¿No estamos ante la Venus del Bosque ante una mezcla semejante de prosaísmo e idealización que la que don Quijote forma con el nombre Dulcinea del Toboso? Carrizales ha inventado en su imaginación a la sublime Venus del Juglar; su cuidado lo inmuniza contra la sórdida soledad de su realidad y lo aleja de la mujer real para transformarla en un personaje mítico extraliterario. La Venus del Juglar es, como Dulcinea, una invención de Carrizales, quien la desliga y arranca de su «destino rústico», como hiciera don Quijote con la rústica Aldonza Lorenzo; le queda al lector abierta la interpretación del personaje, visto como uno de los símbolos más trascendentes, contradictorios y paródicos del sentimiento amoroso.

La descomposición y quiebra moral de Leonor se plasma magistralmente en el capítulo 43, con el recuento cuantitativo de los percances extramatrimoniales, la carrera intermitente de invitados a Santa Bárbara, tantos que, como cuenta el narrador, «se pierde el interés, la cuenta y los motivos» (2002: 154); Leonor se transforma en una hetaira de tierra de murgaños que, como las homólogas del mundo griego o una especie de geisha japonesa, ejerce la prostitución y goza de gran prestigio social; tampoco es ajena a la quiebra moral la perversión moral con que había actuado Carrizales, quien se vanagloriaba ante el gremio de cazadores de manejar a su antojo los sentimientos y resortes de su mujer: «los amores, las culpas, los remordimientos, las euforias de la penitencia» y que «labraba los perfiles titiriteros de la perdición, que él ponía en el camino oportuno al hombre elegido», orgulloso de ser «el artífice de la infamia, el minucioso orfebre de la inmoralidad y la impudicia que salvaguardaba la sustancia conyugal con adulterios funcionales» (2002: 156). Es aquí donde nos parece que la recreación que emprende Hidalgo Bayal cobra aún más fuerza, llevando a su cénit la dramática incertidumbre que rodea la existencia humana, cuando en ella dominan las antítesis, los ritmos afectivos convulsos, las actitudes morales antagónicas, la predilección por lo excéntrico -subrayado este aspecto por las experiencias indianas y por los conflictos oscuros en que se debaten los personajes-, y se impone la idea del «eterno retorno» nietzscheano, que confiere universalidad a la experiencia humana. Amad a la dama se construye sobre la premisa de la vulnerabilidad y la fluctuación del comportamiento humano, que se encuentra a merced de los impulsos del capricho, los celos, las pasiones, los sentimientos, o la razón; en este sentido, consideramos que estamos ante una novela «abierta», 
calificativo con que Juan Bautista Avalle-Arce definió la obra cervantina, que enfatiza la ambigüedad y la apertura de la naturaleza humana (1975: 67-69).

Posteriormente, Leonor suspende el comercio amoroso mantenido hasta entonces, guarda luto y durante unos meses se enclaustra en la mansión de Santa Bárbara con la compañía y cuidados de la mulata Guiomar y del negro Luis, durante los cuales se entrega a la contemplación de su vida asceta; después parte, no se sabe si con destino a Venecia para satisfacer el deseo manifestado por Carrizales antes de morir, o a Roma para visitar al Papa y recibir de él la absolución de sus pecados, o a Madrid. Con la desaparición de Leonor se apaga el esplendor de la mansión; con imagen certera se nos cuenta que «la vegetación salvaje y agresiva inundó el jardín, atacó las paredes, convirtió en muda la hache mayúscula de la planta» (2002: 164); el vergel del jardín edénico se torna «paraje áspero y monstrenco» $\mathrm{y}$, tras treinta años de abandono, se diluyen los signos de vida. Solo sobreviven las ruinas. Al igual que uno de los héroes de Camus, el emperador Calígula, Carrizales muere sabiendo que «los hombres mueren y no son felices», lo cual entraña cierta denuncia de lo absurdo de una existencia a la que no se encuentra sentido. Una vez que han sido quebrantados los pilares que sostienen la vida humana, la libertad y el amor, se imponen la soledad y el nihilismo.

\section{PILARES DE LA NARRATIVA BAYALIANA}

Amad a la dama se sustenta en los tres pilares que sostienen la producción literaria bayaliana: la calidad poética, la autonomía constructiva y la intuición moral subyacente. Si en el acto de lectura el lector se deleita en la elección de las palabras y advierte la autonomía y el rigor constructivo del texto, la obra adopta la novela ejemplar cervantina como soporte y pretexto. Pero incluso, en casos como este, donde la crítica puede subrayar la genealogía de las fuentes nutricias, se aprecia la primacía de los hechos que ocurren o se cuentan, es decir, la primacía de lo narrado sobre la adecuación verosímil o no a la realidad de la ficción, de la trama sobre el tema (los celos).

Amad a la dama es una extraordinaria recreación de una de las novelas ejemplares. Podemos preguntarnos: ¿por qué esta novela ejemplar y no otra? Probablemente porque el calificativo «extremeño» permite recrear de manera lúdica e ingeniosa el territorio bayaliano de Murania y prolongar los juegos lingüísticos, tan cervantinos y bayalianos, pues ante la dilogía del término «extremeño» se establece el juego con el lector, que puede interpretar que está ante unos celos extremos.

Amad a la dama alcanza la genialidad de la novela ejemplar cervantina. De acuerdo con el binomio «formas abiertas» y «formas cerradas» formulado por Heinrich Wölfflin en Kunstgeschichtliche Grundbegriffe, en la recreación bayaliana nos encontramos ante una forma abierta, una fábula intemporal, caracterizada por la disolución de las formas lineales, la redefinición de los 
caracteres y de la trama, la interpenetración de los planos físico, psicológico y espiritual que derivan en un patetismo trascendental. Junto a las correspondencias de temas y personajes y a los logros narrativos (el ordenamiento de la trama, el diseño de los elementos simbólicos, la caracterización de los personajes, la pureza del lenguaje, etc.), se observan otros ingredientes cervantinos y bayalianos: escenarios compartidos, juegos de ingenio, el humor y la ironía, la concepción del amor como fuerza cósmica y existencial, el perspectivismo en el análisis de la realidad, etc.

Partiendo de la utilización que el escritor extremeño hace de las funciones del lenguaje de Karl Bühler como procedimiento de clasificación narrativa (novela representativa o referencial, novela apelativa y novela expresiva), consideramos que nos ofrece Hidalgo Bayal una novela expresiva, que «crea y recrea un mundo poético paralelo a la realidad o alternativo», como él mismo sostiene (2013: 19).

Amad a la dama es la segunda novela en la que la llegada de un forastero pone de relieve las hipocresías y miserias latentes en una ciudad y en unos grupos sociales concretos. La llegada de Lucas Cálamo, en Mísera fue, señora, la osadía; de Felipe Carrizales, en esta; y del personaje anónimo en Paradoja del interventor son las generadoras de un conflicto que, en ninguno de estos casos, se traslada al entorno urbanístico y social, sino que permanece en el personaje. Por este motivo, consideraba el escritor en dicha conferencia, que, en vista de que ninguno de estos personajes (Lucas Cálamo, Felipe Carrizales y el interventor) acaba por conquistar la ciudad, no se puede hablar del «efecto forastero», sino más bien del «síndrome del agrimensor», pues estamos ante «pobres aprendices de ese héroe de la épica moderna, que da vueltas inútilmente en torno a un castillo inaccesible». No nos detenemos en estos aspectos que, indudablemente, son interesantes por las numerosas resonancias literarias que presentan con Franz Kafka o Dino Buzzati, etc., pues constituirían el objeto de otra investigación.

Para ir concluyendo, diremos que Amad a la dama es una recreación $\mathrm{y}$, al mismo tiempo, una desacralización de una de las novelas ejemplares cervantinas, un ejercicio osado y original de reescritura, en la que el escritor extremeño se decanta por la aventura del lenguaje, como ya hiciera en Mísera fue, señora la osadía y, en menor medida, en El cerco oblicuo y en Campo de amapolas blancas. Los juegos lingüísticos se extienden desde las pretensiones de reconstruir artificialmente unas lenguas primitivas autóctonas, como el húrdalo o el sérbolo, que le llevan a atribuir a Leonor la «sensualidad sérbola» de la escultórica e inexistente Venus del Bosque (2002: 32), hasta recrear las expresiones cortazarianas que figuran en Rayuela [«Apenas él le amaba el noema, a ella se le agolpaba el clémiso y caían en hidromurias, en salvajes ambonios, en sustalos exasperantes» (1963: 428)] para definir el estado melancólico de Leonor: «Leonor empezó a caer de nuevo en lánguidas hidromurias, en taciturnos ambonios y en prolongados espásmulos anémicos» (2002: 128). De esta manera Hidalgo Bayal, demiurgo lingüístico, ignorando el diccionario, inventa palabras e invita al lector, 
como hiciera Cortázar, a prolongar con su imaginación el significado de la literatura; adquiere así la obra literaria una dimensión lúdica, que permite que el autor defina las coordenadas sobre las que el lector establece el juego. Las similitudes con la fuente nutricia se manifiestan en el plano discursivo sintáctico por la proliferación de amplios períodos oracionales, la presencia de numerosos elementos conectores y partículas ilativas; las recurrentes asociaciones de ideas y juegos mentales; la agudeza lingüística; el dinamismo y agilidad narrativas; el dominio de la plasticidad con que plasma el pintoresquismo cervantino; el artificio y la reiteración; el énfasis y profusión de imágenes, etc. Con precisión literaria y rigor léxico extraordinarios, con una voluntad de estilo que sabe dar razón de cada palabra que escribe, Hidalgo Bayal juega con el lenguaje a través de la tensión fonética, arquitectónica, poética que crean las mismas palabras y trasciende los límites del lenguaje. Necesita, asimismo, como toda la obra bayaliana, un lector diestro en competencia lingüística y literaria, que acierte desde su asombro y perplejidad a leer entre líneas y a rescatar las referencias literarias que con frecuencia pueden permanecer arcanas a un lector no tan avezado; precisa un lector que sea capaz de seguir el juego de símbolos trazados en aparente sencillez y que esconden una estructura laberíntica.

Amad a la dama apuesta con su gran fuerza fabuladora e imaginaria por un lector activo y cómplice; lo invita a reconstruir y prolongar la fábula narrada y a construir su propia novela, indagando sobre la realidad o ficcionalidad de los ámbitos geográficos y de la toponimia (Hoya de Juglar; los bosques de Los Huranes y de Los Angores; el río Jayón; la Cuerda del Serbo, etc.); lo induce a adoptar una postura personal respecto a las cuestiones humanas planteadas a través de unos personajes que despiertan con sus fragilidades unos dilemas de alcance universal. Parodia los mitos y no prescinde de la finalidad irónica y cómica cervantina; juega con los personajes literarios y con las formas narrativas; introduce técnicas del cinemascope que renuevan el marco narrativo; juega con la ambigüedad; supera los límites del realismo por la vía de la alusión; aúna el juego literario con la dimensión estética, poética y metafísica; entrelaza la fabulación de la historia con la crítica artística (musical, escultórica, cinematográfica y pictórica), en la que se recrea especialmente en el capítulo 37, que permite vislumbrar la fuerza y la necesidad de la belleza. Contrasta la dimensión lúdica de esta obra, con la que Hidalgo Bayal tributa homenaje a Cervantes, con la proyección existencialista de la trama, otro recurso de ingenio del escritor extremeño.

Amad a la dama se muestra, en definitiva, como una experimentación creativa y estética, impregnada de reflexiones de gran profundidad ideológica y literaria, cuyo planteamiento suscita la respuesta del lector. 


\section{BIBLIOGRAFÍA CITADA}

Alfonso, Pedro (1948). Disciplina clericales. Edición y traducción del texto latino Ángel González Palencia. Madrid: CSIC, Instituto Miguel Asín.

Álvarez Martínez, José Luis (1990). «Sobre las dos versiones de la novela El celoso extremeño de Cervantes», Revista de Estudios Extremeños. 46, pp. 121-155.

Avalle-Arce, Juan Bautista (1975). Nuevos deslindes cervantinos. Barcelona: Ariel.

Avalle-Arce, Juan Bautista (2003). «Introducción y notas», en Novelas ejemplares. Madrid: Castalia, II, pp. 7-43.

Ayala, Francisco (1954). «Experiencia viva y creación poética. Un problema del Quijote», La Torre. Universidad de Puerto Rico (Abril-junio 1954); fue reeditado en Experiencia e invención e incluido en "Los clásicos», Los ensayos. Teoría y crítica literaria. Prólogo de Helio Carpintero. Madrid: Aguilar, 1972, pp. 659-684.

Bonilla y San Martín, Adolfo (1916). Cervantes y su obra. Madrid: Francisco Beltrán.

Casalduero, Joaquín (1969). Sentido y forma de las Novelas ejemplares. Madrid: Gredos, 2. ${ }^{\mathrm{a}}$ ed.

Castro, Américo (1957). «El celoso extremeño de Cervantes», en Hacia Cervantes. Madrid: Taurus, pp. 301-327.

Cervantes, Miguel de (2009). Don Quijote de La Mancha. John Jay Allen (ed.). Madrid: Cátedra, Col. «Letras Hispánicas», 100, 28. ${ }^{\mathrm{a}}$ ed.

Cervantes, Miguel de (2001). Novelas ejemplares, II. Jorge García López (ed.), estudio preliminar de Javier Blasco. Madrid: Crítica.

Cervantes, Miguel de (2003). Novelas ejemplares, II. Juan Bautista Avalle-Arce (ed.). Madrid: Castalia.

Cirot, Georges (1929). «El celoso extremeño et L'histoire de Floire et Blanceflor», Bulletin Hispanique. XXI, pp. 138-143.

Cortázar, Julio (1963). Rayuela. Buenos Aires: Editoral Sudamericana.

Dunn, Peter N. (1973). «Las Novelas ejemplares», Suma cervantina. J. B. Avalle-Arce y E. C. Riley (eds.). Londres: Tamesis, pp. 81-118.

Forcione, Alban K. (1982). Cervantes and the Humanist Vision. A Study of Four Exemplary Novels. Princeton: Princeton University Press.

Gómez Íñiguez, Laura (1991). «Humor cervantino: El celoso extremeño», en Actas del II Coloquio Internacional de la Asociación de Cervantistas (Alcalá de Henares, 6-9 de noviembre 1989). Barcelona: Anthropos, pp. 633-639.

González Palencia, Ángel (1925). «Un cuento popular marroquí y El celoso extremeño de Cervantes», en Homenaje ofrecido a Menéndez Pidal. Madrid: Hernando, I, pp. 417-423.

Gutierre de Cetina. Obras de Gutierre de Cetina. J. Hazañas y la Rúa (eds.). Sevilla: Imprenta de Francisco de P. Díaz, 1895, 2 vols.

Hidalgo Bayal, Gonzalo (2002). Amad a la dama. Gijón: Llibros del Pexe.

Hidalgo Bayal, Gonzalo (2013). «El efecto M.». En: Felipe Aparicio Nevado (ed.). El efecto M. Territorios narrativos de Gonzalo Hidalgo Baya. Jaraíz de la Vera: Ediciones La Rosa Blanca, pp. 19-30.

Humboldt, Alejandro de (1991). Viaje a las regiones equinocciales del Nuevo Continente. Caracas: Monte Ávila Editores, 2. ${ }^{\text {a }}$ ed., 5 Vols.

Ingarden, Roman Witold (1931). Das literarische Kunstwerk. Eine Untersuchung aus dem Grenzgebiet der Ontologie, Logik und Literaturwissenschaft. Halle: Max Niemeyer.

Mañero Lozano, David (2000). «Por Hepila famosa: posible alusión a Jerónimo de Urrea en el Quijote de 1605», Revista de Filología Española. LXXX, pp. 215-221.

Marín Pina, M. ${ }^{a}$ Carmen (2002). «Clarisel de las Flores de Jerónimo de Urrea», Edad de Oro. XXI, pp. 451-479.

Menéndez Pelayo, Marcelino (1905). «Cultura literaria de Miguel de Cervantes y elaboración de El Quijote», Revista de Archivos, Bibliotecas y Museos. V, pp. 309-339. 
Molho, Maurice (1990). «Aproximación al celoso extremeño», Nueva Revista de Filología Hispánica. 38, 2, pp. 743-792.

Percas de Ponseti, Helena (1994). «El 'misterio Escondido' en El celoso extremeño», Cervantes: Bulletin of the Cervantes Society of America. 14.2, pp. 137-153.

Soriano, Marc (1972). Les Contes de Perrault. Culture savante et traditions populaires. Paris: Gallimard.

Pozuelo Yvancos, José María (1988). «Poética de la recepción», en Teoría del lenguaje literario. Madrid: Cátedra, 1992, pp. 105-127.

Wölfflin, Heinrich (1915). Kunstgeschichtliche Grundbegriffe: Das Problem der Stilentwickelung in der neueren Kunst. München: Bruckmann.

Recibido: 28 de mayo de 2013

Aceptado: 4 de octubre de 2013

\title{
Resumen
}

Este artículo analiza la recreación narrativa de la novela ejemplar cervantina, El celoso extremeño, que emprende Gonzalo Hidalgo Bayal en Amad a la dama (2002). Estudiamos las correspondencias y paralelismos que presenta la novela con las dos versiones de la novela ejemplar, con el objetivo de mostrar que el escritor extremeño se sitúa en el continuum de la tradición literaria cervantina, retomando muchos elementos de la novela ejemplar: la trama, la caracterización de los personajes, el diseño de los elementos simbólicos, la pureza del lenguaje, etc.

Palabras clave: Cervantes; Gonzalo Hidalgo Bayal; Novelas ejemplares; recreación cervantina; Amad a la dama; El celoso extremeño.

Title: Narrative Recreation of El celoso extremeño: amad a la dama, by Gonzalo Hidalgo Bayal.

\begin{abstract}
This article analyzes the narrative recreation of Cervante's exemplary novel, El Celoso extremeño, that Gonzalo Hidalgo Bayal undertakes in Amad a la dama (2002). We study the corresponding similarities and parallels that Bayal's novel shares with both versions of the exemplary novel. Our aim is to show that the Extremaduran writer's work is a continuum of the literary Cervantine tradition, reusing many elements of the exemplary novel: the plot, the depiction of characters, the design of symbolic elements, the purity of language, etc.
\end{abstract}

Key words: Cervantes; Gonzalo Hidalgo Bayal; Exemplary Novels; Recreation of Cervante's exemplary novel; Amad a la dama. 